\title{
A Life Cycle Assessment (LCA) Approach on the Production of Sago Sucker for Cultivation
}

\author{
NAJWA SULAIMAN*, NIK SASHA KHATRINA KHAIRUDDIN, MAIZAN ISMAIL, CHEE \\ BENG YEOH \& FARAH KHUWAILAH AHMAD BUSTAMAM
}

\author{
Malaysian Palm Oil Board, No.6, Persiaran Institusi, Bandar Baru Bangi, 43000 Kajang, Selangor, Malaysia \\ *Corresponding author: najwa.sulaiman@ mpob.gov.my

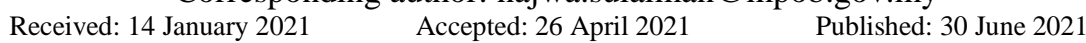

\begin{abstract}
Sago palm is one of the commodities being cultivated and traded in Malaysia for its high starch content. Sago seedling, or commonly referred to as sucker, is the planting material for sago cultivation. This paper discusses the life cycle assessment approach for the calculation of life cycle inventory for the production of one sago sucker. In this study, the functional unit is defined as one sago sucker. The process starts from the reception of suckers from suppliers, raft preparation, planting sago suckers in rafts, fertilization, and ends with transportation of the suckers to the plantation. Interviews and data verification were done on-site at the Crop Research and Application Unit (CRAUN) Sungai Talau Research Station. LCI data showed that water was the main input for the production of sago sucker, followed by diesel for transportation, pesticides, and fertilisers. The outcome of this study provides a basis or guideline to planters in implementing sago best agricultural practices for the production of sustainable sago.
\end{abstract}

Keywords: Life cycle assessment, life cycle inventory, sago, sucker

Copyright: This is an open access article distributed under the terms of the CC-BY-NC-SA (Creative Commons Attribution-NonCommercial-ShareAlike 4.0 International License) which permits unrestricted use, distribution, and reproduction in any medium, for non-commercial purposes, provided the original work of the author(s) is properly cited.

\section{INTRODUCTION}

Malaysia is one of the world's major sago producers (Jong, 2018) for which it is mostly cultivated in Sarawak peatlands with 67,957 ha planted in Mukah. In 2017, Sarawak state recorded sago export value of RM 86.8 million to various destinations in Asia, including Peninsular Malaysia (Shamsul, 2018). Sago is grown as a commercial crop for the production of sago starch as well as animal feed (Singhal et al., 2008). In Malaysia, sago starch is considered the main carbohydrate source, with annual production of 25 tonnes ha ${ }^{-1}$ of starch (Ishizaki, 1997), which is 3 to 17 times higher than other starch-containing crops such as tapioca, rice, corn and wheat (Karim et al., 2008).

The Land Custody and Development Authority of Sarawak (PELITA) has been involved in sago plantation development since 1987 and intends to commercialise sago plantations by 2020, with 50,000 ha of smallholders' farms being aggressively consolidated and rehabilitated. PELITA has designated a total of 5,152 ha of peatland in Mukah for development of three sago plantations namely, Mukah sago plantation, Dalat sago plantation, and Sebakong sago plantation. The Sarawak State Government agency called Crop Research and Application Unit (CRAUN) was entrusted for plant selection and breeding of high yielding sago varieties.

Sago palm or Metroxylon sagu is a tropical crop that can survive in a harsh swampy peat environment which does not require draining and water quality monitoring (Abd-Aziz, 2002). Sago palm belongs to Palmae Jussieu family, under genus Metroxylon (Flach, 1997). It is commonly grown by suckers which are clustered around the parent palm. The sago palm heighted between 6 and $14 \mathrm{~m}$ and hapaxantic plant in nature where it experiences once-in-a-lifetime flowers and immediately dies thereafter. During the vegetative stage, the plant converts its stored nutrients into starch. The sago starch is located in the pith, which is saturated with starch from the base of the trunk upwards (Pei-Lang et al., 2006). Sago palm undergoes four stages during its life cycle of 12 to 15 years as listed in Table 1 . 
This plant is a high survival plant as it can grow well in swampy acidic peat soil and able to withstand flood, drought, fire and strong wind. However, it grows more slowly on peat soil than on mineral soil (Flach \& Schuiling, 1989). The starch accumulates in the trunk of the palm until the flowering stage with maximum starch content taking place just before the onset of the flowers (Singhal et al., 2008). The starch left unharvested will then be used for the formation of flower and seeds, before the trunk dies (Flach \& Schuiling, 1989).

Other parts of the palm which does not contain starch are utilised in various applications i.e. source of compost, building material, animal feed and paper industry. The rachis of the frond is often used to produce walls where it is fastened between horizontal posts (Singhal et al., 2008). Mats can also be made from the young leaves, while strong leaves can be woven into bags, cages, ropes and food wrappers (Abd Aziz, 2002). The fronds are applicable for pulp and paper making (Abd Aziz, 2002). In food application, sago starch is used as stabilizer and thickener and to substitute corn starch (Singhal et al., 2008). Besides food products, it is utilised to produce adhesive for paper, textiles, and plywood. Pharmaceutical area also benefits from sago starch where it is used as stabiliser (Singhal et al., 2008). It could be also mixed together with other starches for the production of flavor enhancer i.e. monosodium glutamate and fructose syrup for non-alcoholic beverages (Singhal et al., 2008).

Abd Aziz (2002) reviewed on the uses of sago starch as an alternative cheap source of carbon for fermentation process. There were several other studies on the uses of sago palm in food or nonfood products (Yahya et al., 2011; Bhat et al., 2013; Jamaludin et al., 2014; Wahi et al., 2014; Alamaria et al., 2015). Apart from these, sago palms act as carbon sink with the ability to absorb and entrap carbon dioxide from releasing to the environment; this prevalence allows carbon sequestration which further mitigates the issues on greenhouse effect and global warming (Stanton, 1991). Sago palm exhibited better carbon dioxide absorption (289 MT per hectare per year) compared to other crops such as rice, corn and cassava (Bintoro et al., 2010).

Today, the world has become more concerned in the environmental impact of the materials, energy and wastes consumed and produced during the production of various products, processes and activities. In the past 10 years, LCA is used as one of the measures to identify the sustainability of a certain product by evaluating the environmental impact associated with a product, process or activity through identification and quantification of energy and materials used and waste products released into the environment. LCA takes into consideration the impact of the energy and materials used and released to the environment and evaluate opportunities for environmental improvement. The assessment includes the entire life cycle of the product, process or activity, encompassing extraction and processing of the raw material, manufacturing, transportation and distribution, utilisation, maintenance, recycling and finally, disposal (Birkved \& Hauschild, 2006; Hansen, 2007; Avraamides \& Fatta, 2008).

In LCA methodology, LCI is one of the four steps that need to be calculated before evaluating the environmental impact through life cycle impact assessment (LCIA). The aim of LCI is to identify all inputs and outputs in the product's life cycle. At the same time, LCI can be used to highlight areas which have potential for environmental quality improvements through resource conservation and emission reductions (Khairuddin et al., 2013). Therefore, this study aimed to use the LCI to map out all the inputs and outputs required and identify the potential environmental impacts associated with the production of sago suckers in sago nursery.

\section{MATERIALS AND METHODS}

According to ISO 14040 Environmental management - Life cycle assessment (Principles and framework), LCA methodology encompasses four main phases which are: (1) goal and scope definition, (2) life cycle inventory analysis, (3) life cycle impact assessment, and (4) interpretation of results (Halimah et al., 2013). For the purpose of this study, the LCI for sago sucker was based on the energy requirements where the information on resources was collected and assessed within the system boundary.

\section{System Boundary}

The system boundary covered from reception of suckers from supplier to the nursery until transportation to the plantation (Figure 1). Inventory at sago nursery was done in collaboration with CRAUN Research Station located at Sg. Talau 
Table 1. Stages in the life cycle of sago (Flach, 1997)

\begin{tabular}{ll}
\hline \multicolumn{1}{c}{ Stage } & \multicolumn{1}{c}{ Description } \\
\hline $\begin{array}{l}\text { Rosette stage of } 45 \text { months from } \\
\text { seeding. }\end{array}$ & $\begin{array}{l}\text { A period characterised by relatively little growth, the plant forms a total } \\
\text { of } 90 \text { leaves. }\end{array}$ \\
\hline $\begin{array}{l}\text { Bole formation stage of } 54 \\
\text { months. }\end{array}$ & $\begin{array}{l}\text { During this period, the bole elongates to a maximum height and } \\
\text { produces one leaf per month. }\end{array}$ \\
\hline Inflorescence stage of 12 months. & $\begin{array}{l}\text { The plant forms two leaves per month and the rate of starch } \\
\text { accumulation starts to decrease and the starch moves from the lower to } \\
\text { the upper bole. Palms are harvested for starch during this and the next } \\
\text { period. }\end{array}$
\end{tabular}

Fruit ripening stage of 24 months. Flowers converted to fruits, and completion of sago life cycle.

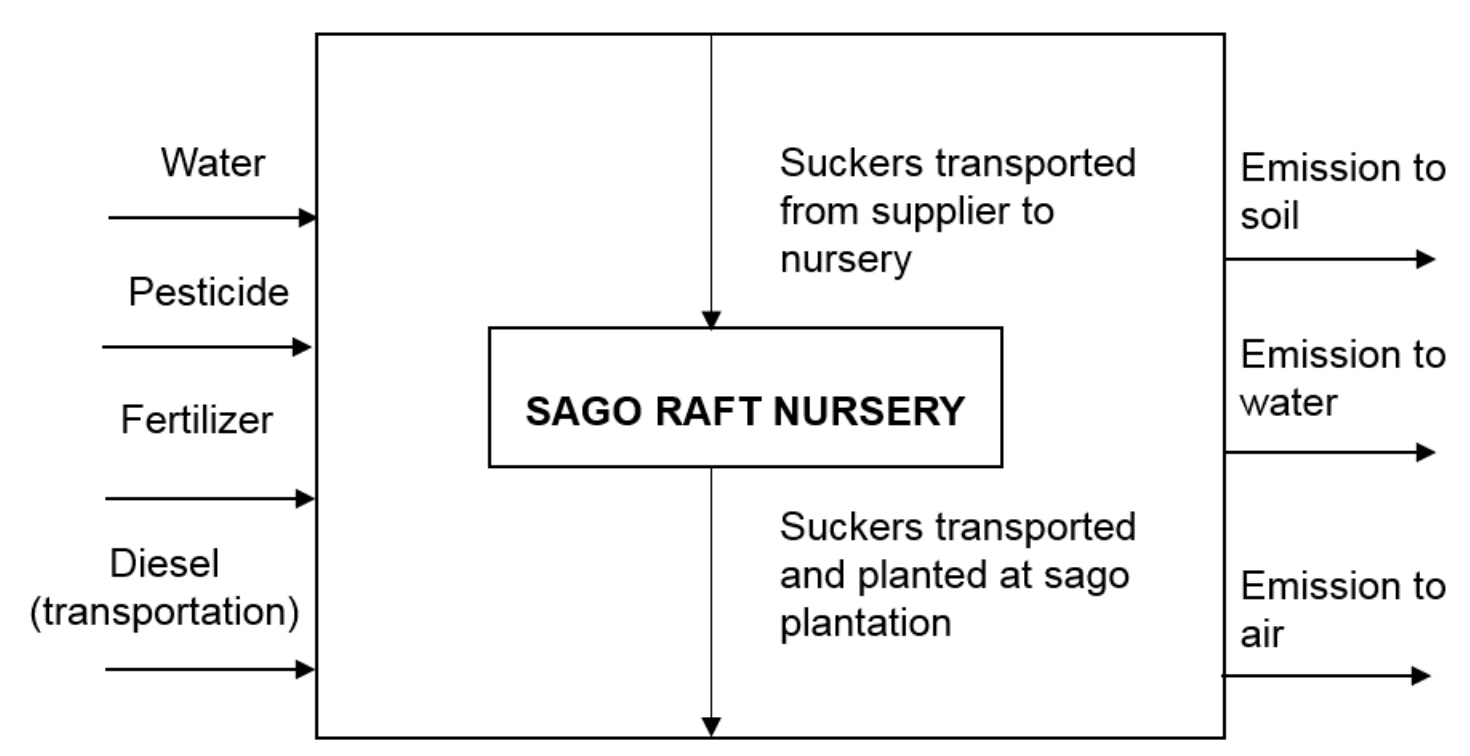

Figure 1. System boundary for the production of sago sucker

Mukah, Sarawak. The state-owned agency is mainly responsible for the research and development of sago industry in Malaysia. The inventory involved reception of suckers from suppliers, raft preparation, planting sago suckers in rafts, fertiliser application and transportation of suckers to the plantation. Data was collected and recorded for subsequent evaluation. Such system boundary was chosen to reflect the actual agricultural practice at sago nursery cultivation area. For comparison purpose, a functional unit, which denotes as a single unit of sago sucker, was applied in this study. The design of our LCA study generally followed the concept of cradle-to-gate where all operations and practices as illustrated in
Figure 1. Any aspects that were not spelt out in the scope of study were excluded from the system boundary.

\section{Data Collection and Life Cycle Inventory}

Inventory data on sago nursery and cultivation were obtained from CRAUN Research Sdn. Bhd. Each process's inventory data were collected directly from the sago nursery based on questionnaires and interviews distributed to CRAUN Research Station at the selected sago nursery. The received data were validated by onsite visit and interviews, telephone conversation and email communications as a confirmative measure. 


\section{RESULTS AND DISCUSSION}

\section{Production of Sago Suckers}

In principle, sago propagates via vegetative suckers as shown in Figure 2a, emerged from the parent plant's roots or lower trunks (Singhal et al., 2008), and propagates through seeding due to issues associated with sterility and viability (McClatchey et al., 2006). Suckers are more commonly used than seeds, as most sago palms are harvested before the flowering stage (Howell et al., 2015). Unlike most other crops, sago does not require any replanting as the suckers are continuously produced through vegetative route (Chew et al., 1998). Seven suckers were maintained throughout the propagation process to avoid direct sunlight and nutrient competition between suckers and the parent palm. Limiting to only seven suckers at one time of planting could delay the growth of new suckers, which is more favourable to the parent plant to monopoly as much nutrient for its growth. Technology modernisation at the nursery (i.e. utilisation of rafts or polybags) enables the possibility of planting sago at larger scale plantation through the careful selection of good quality suckers, sucker extraction from the parent palm and development of sago planting material from extensive breeding studies (Mohamed Naim et al., 2016).

The suckers were carefully removed from the parent palm by clean cutting at the surface of the sucker vertically to obtain an L-shape at the bottom of the sucker with undamaged roots. Extraction of the suckers must be done from the matured parent palm for higher survival and readiness to grow independently. The suckers were then transferred onto the rafts (Figure $2 b$ ) within three days after cropping and nursed for three months before new leaves and roots to surface, indicating the replanting readiness (Howell et al., 2015).

The summary of sago sucker characteristics in the nursery is listed in Table 2. These characteristics were calculated based on the information gathered from the questionnaires and interviews, which cover suckers planted in a raft, utilisation of water, fertiliser and pesticides, mean to transport suckers from the parent palm to the nursery and plantation sites, and mortality rate.

A total of 120 to 150 suckers (average of 135 suckers) were placed in a raft with a $1.22 \mathrm{~m} \mathrm{x} 3.66$ $\mathrm{m}$ raft dimension. The rhizomes were immersed in a three-quarter deep soil with running water. Stagnant water must be avoided to prevent yellowish due to lack of nutrients and thus inhibits the growth of the suckers. The raft was made of bamboo measuring $3.66 \mathrm{~m} \times 0.91 \mathrm{~m}$. The bamboos were cut into 10 to 12 smaller pieces and tied with packing string. The L-shape rhizomes were grown on the raft, while the round shape rhizomes were separated and grown in polybags. New bamboos are continuously being acquired to produce new rafts and replace bamboo on the upper part of the raft as it could become flimsy after period of usage due to exposure to sunlight.

Polybags were only used for the treatment of pest-infected suckers, as well as suckers that are lacking nutrient (rehabilitation) and experiencing drought season. However, this process is excluded from the inventory calculation as planting in polybags is seldom carried out.

Pruning of the suckers is done three times a year as a control measure to regulate the density of the suckers. If the suckers are left to grow uncontrollably, they will negatively compete against each other for sunlight and nutrients.

Water supply for the nursery and plantation is sourced from the river nearby, and therefore, the amount of water consumption was not measured and recorded. The assumption made was all the rafts received the same amount of water, i.e. $1 \mathrm{~L}$ of water for every sucker.

According to CRAUN, fertiliser was sprayed only once every three months through a foliar spray. Usually, nitrogen phosphorus potassium or NPK fertiliser without hormone was applied using a knapsack sprayer with a recommended capacity of $16 \mathrm{~L}$. The amount of fertiliser applied was calculated based on sprayer's capacity, the average number of suckers per raft, and the percentage of NPK compositions. The calculation for fertiliser application is as Eq. (1):

Fertiliser application

$=16 \mathrm{~L}$ fertiliser $\div 30$ rafts $\div 135$ suckers per raft

$=3.948 \mathrm{E}-03 \mathrm{~L}$ of fertiliser per sucker

This value was then multiplied with the compositional percentage of NPK applied. As an example, nitrogen is $8 \%$, giving $3.1584 \mathrm{E}-04 \mathrm{~L}$ of nitrogen per sucker. It was previously mentioned that two types of fertilisers of different compositions were used in this study, i.e. Humibox 
Table 2. Characteristics of sago sucker in the nursery

\begin{tabular}{|c|c|}
\hline Input & Amount \\
\hline Sucker per raft & 135 suckers \\
\hline Water & 1L/sucker \\
\hline \multicolumn{2}{|l|}{ Fertiliser: } \\
\hline (i) Humibox & Once/raft \\
\hline $\mathrm{N}, 8 \%$ & 3.1584E-04 L/sucker \\
\hline $\mathrm{P}_{2} \mathrm{O}_{3}, 4.5 \%$ & 1.7766E-04 L/sucker \\
\hline $\mathrm{K}_{2} \mathrm{O}, 10.5 \%$ & 4.1454E-04 L/sucker \\
\hline (ii) Fertisol & Once/raft \\
\hline $\mathrm{N}, 11 \%$ & 4.3428E-04 L/sucker \\
\hline $\mathrm{P}_{2} \mathrm{O}_{5}, 8 \%$ & 3.1584E-04 L/sucker \\
\hline $\mathrm{K}_{2} \mathrm{O}, 6 \%$ & 2.3688E-04 L/sucker \\
\hline Pesticide: & Alternately \\
\hline Malathion, $84 \%$ & 1.105E-03 L/sucker \\
\hline Chlorpyrifos, $21.2 \%$ & 2.7899E-04 L/sucker \\
\hline Paraquat, $13 \%$ & 1.7108E-04 L/sucker \\
\hline Thiram, $80 \%$ & 1.0528E-03 L/sucker \\
\hline
\end{tabular}

Distance travelled from supplier to CRAUN (Three-

tonne lorry, 3000 suckers/trip/week) - two way

1. Betong, $400 \mathrm{~km}$

$0.1333 \mathrm{~km} /$ sucker

2. Balingian, $100 \mathrm{~km}$

$0.0333 \mathrm{~km} / \mathrm{sucker}$

3. Mukah, $80 \mathrm{~km}$

$0.0267 \mathrm{~km} / \mathrm{sucker}$

4. Dalat, $40 \mathrm{~km}$

$0.0133 \mathrm{~km} /$ sucker

Average distance travelled

$0.0517 \mathrm{~km} / \mathrm{sucker}$

\section{Distance travelled from CRAUN to plantation}

(Three-tonne lorry, 850 suckers/trip/week) - two way

1. Mukah, $80 \mathrm{~km}$

$0.0941 \mathrm{~km} /$ sucker

2. Sebakong, $240 \mathrm{~km}$

$0.2824 \mathrm{~km} /$ sucker

3. Dalat, $40 \mathrm{~km}$

$0.0471 \mathrm{~km} /$ sucker

Average distance travelled

$0.1412 \mathrm{~km} / \mathrm{sucker}$

Mortality rate $(\%)$ $25 \%$ 

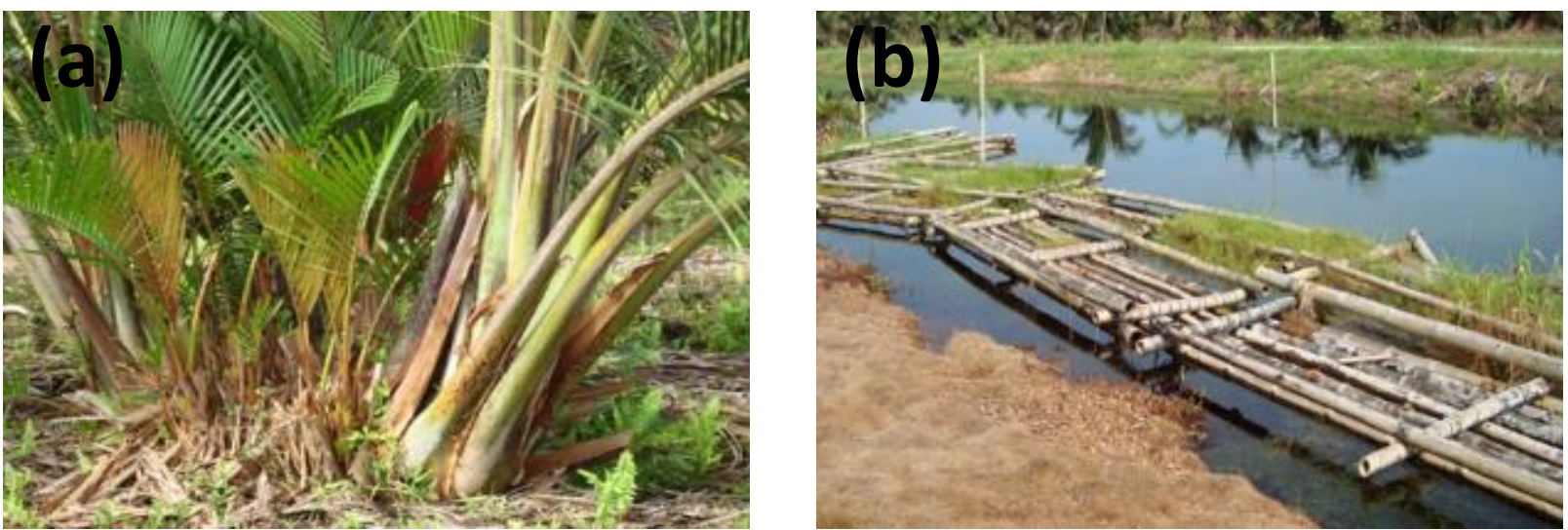

Figure 2. (a) Sago suckers emerged from roots or lower trunks of parent plant; (b) Rafts made from bamboo for cultivation of sago suckers

and Fertisol; an average value was calculated for each composition of nitrogen $(\mathrm{N})$, phosphoric acid $\left(\mathrm{P}_{2} \mathrm{O}_{5}\right)$ and potassium oxide $\left(\mathrm{K}_{2} \mathrm{O}\right)$.

Pesticides were only applied if the pest attack was identified. The dosage applied followed the manufacturer recommendation or less, depending on the infection severity. Spraying was done two or three times per year. The application of pesticides at the nursery was lesser than applied to the field. Among the pesticides used were malathion, chlorpyrifos, paraquat and thiram. A knapsack sprayer containing $16 \mathrm{~L}$ of pesticide is sufficient to treat 30 rafts of suckers. Similar to the calculation for fertiliser, the calculation is as Eq. (2):

Pesticide application

$=16 \mathrm{~L}$ pesticide $\div 30$ rafts $\div 135$ suckers per raft

$=3.948 \mathrm{E}-03 \mathrm{~L}$ of pesticide per sucker

As different pesticide assigns the specific percentage of active ingredient (a.i., \% v/v), the value obtained from Equation 2 needs to be multiplied with the percentage of ingredient a.i. For example, malathion a.i. is $84 \%$, giving $3.3163 \mathrm{E}-03$ $\mathrm{L}$ per sucker and divided by each round of spraying, i.e. three months to give the value of 1.1054E-03 L of malathion per sucker (Equation 3). Similar calculations Eq. (3) are also applied for other pesticides used.

Malathion application

$=3.948 \mathrm{E}-03 \mathrm{~L}$ of pesticide per sucker $\mathrm{x} \quad 84 \%$ a.i.

$\div 3$ months

$=1.1054 \mathrm{E}-03 \mathrm{~L}$ of malathion per sucker
The suckers are transported to CRAUN Sg. Talau Research Station by a three-ton lorry which can accommodate 3000 suckers per trip. The frequency of the trip is based on the request, usually once per week. The distance between CRAUN Sg. Talau Research Station from Betong, Balingian, Mukah and Dalat is 200, 50, 40 and $20 \mathrm{~km}$, respectively. The distance travelled to transport 3000 suckers from the supplier for each trip was calculated by dividing the distance by the number of suckers. For example, the distance travelled for every sucker from supplier in Betong is $0.1333 \mathrm{~km}$ (400 km/3000 suckers). A similar calculation was done for other locations to achieve the total distance travelled for a single sucker of $0.2067 \mathrm{~km}$. The average distance travelled from all the four suppliers was calculated as $0.0517 \mathrm{~km}$ per sucker.

From the nursery, the suckers were transported to the plantations owned by PELITA in Mukah, Dalat and Sebakong. Each trip involved the transportation of 700 to 1000 suckers daily to all three plantations. The trip from CRAUN Sg. Talau Research Station to Mukah plantation took about 1 hour to travel for $40 \mathrm{~km}$, while a one-way trip to Sebakong plantation is $120 \mathrm{~km}$ and another $20 \mathrm{~km}$ to reach Dalat plantation. The average distance travelled by a singular sucker to all the plantations was $0.1412 \mathrm{~km}$ using a similar calculation.

The mortality rate during transportation ranged from $20 \%$ to $30 \%$, and therefore the average value of $25 \%$ has been used as a basis for data interpretation in this study. The suckers or planting material could be purchased from a nursery that is a distant away (up to a few hundreds of kilometres) from the plantation. The delay for planting due to 
long distance travelling is likely to give higher mortality rates to the suckers.

\section{Life Cycle Inventory}

Based on CRAUN Research Sdn Bhd's existing information and data obtained from the site visit to the CRAUN Sg. Talau Research Station, a LCI for the production of one sago sucker was calculated based on the mortality rate of $25 \%$, as listed in Table 3. The values from Table 2 were used to determine the amount of energy input to prepare one sago sucker. Inputs such as diesel used for transportation of suckers from suppliers to the nursery and therefore to the plantation, water, fertilisers and pesticides used for the growth were taken into consideration in the study.

The water used was re-calculated based on a $25 \%$ mortality rate which gave $1.25 \mathrm{~L}$ of water needed per sucker. The amount of fertiliser and pesticide needed for each sago sucker was also recalculated based on the $25 \%$ of mortality rate, average $\mathrm{N}, \mathrm{P}_{2} \mathrm{O}_{5}$ and $\mathrm{K}_{2} \mathrm{O}$ content, and the average amount of pesticides applied. The energy in term of diesel consumption was calculated based on converting $1 \mathrm{~L}$ diesel equivalent to $35.9 \mathrm{MJ}$ (Deep Resource, 2012). The calculation is as Eq. (4):

Diesel consumption (in MJ)

$=$ total distance travelled by sucker $\div$ diesel consumption of lorry $\mathrm{x}$ conversion factor

$=0.1928 \mathrm{~km} \div 8.5 \mathrm{~km} / \mathrm{L}$ x $35.9 \mathrm{MJ}$

$=1.0196 \mathrm{MJ}$

Table 3. LCI for the production of one sago sucker

\begin{tabular}{lc}
\hline Input & Amount (L) \\
\hline Water & 1.25 \\
Fertilisers: & \\
$\mathrm{N}$ & $4.6883 \times 10^{-4}$ \\
$\mathrm{P}_{2} \mathrm{O}_{5}$ & $3.0844 \times 10^{-4}$ \\
$\mathrm{~K}_{2} \mathrm{O}$ & $4.0714 \times 10^{-4}$ \\
& \\
Pesticide (a.i): & \\
Malathion & $1.3818 \times 10^{-3}$ \\
Chlorpyrifos & $3.4874 \times 10^{-4}$ \\
Paraquat & $2.1385 \times 10^{-4}$ \\
Thiram & $1.3160 \times 10^{-3}$ \\
& \\
Diesel for & $0.0284(1.0196 \mathrm{MJ})$ \\
transportation & \\
\hline
\end{tabular}

For the production of one sago sucker, it was found that water was the primary input, followed by diesel for transportation, malathion, thiram, nitrogen fertiliser, potassium fertiliser, chlorpyrifos, phosphorus fertiliser and paraquat. Water is much expected to be the primary input in the production of suckers because the suckers need to be immersed and treated in water for three months before transplanting to the plantation. The increase in fertilisers utilisation for commercially grown sago palms is required to ensure that all suckers received sufficient nutrients before harvest. As sago suckers are planted in water, the fertilisers can be easily washed away by the water.

Pests rarely attack sago; hence pesticides are seldom being applied in the nursery or plantation. Rynchophorus schach, the beetles that infest sago trunk at the plantation, benefit the growers as the beetle larvae are consumed as a fine delicacy by the locals (Chew et al., 1998). However, at the nursery stage, the main challenge is to control monkeys and wild boars that dig and consume the suckers (Flach, 1997). Inventory data also showed that the volume of pesticides applied was very low, which is 5.1043E-03 L per one sago sucker. The production of one sago sucker uses 1.1844E-03 L of NPK fertiliser.

Transportation includes delivery of suckers to the nursery and the plantations. Suckers were supplied to the nursery from several sources in Betong, Balingian, Mukah and Dalat, and transported to several plantations in Mukah, Sebakong and Dalat. The distance travelled was considered full round trips with a lorry load of three tonnes (3000 suckers from suppliers and 850 suckers to plantations). In general, the total input needed to produce one sago sucker was minimal.

\section{CONCLUSION}

Our research findings showed that water was the main input for the production of one sago sucker followed by fossil fuel, chemicals and fertilisers. The outcome from this may help identify critical areas for improvement of environmental performance and reduce the environmental impact, i.e. greenhouse gas emission $\left(\mathrm{CO}_{2}\right.$ equivalent) to produce sago sucker. Furthermore, our work provided a holistic understanding of the environmental performance for improvement, enhancing commercialisation and market opportunity for sago production in Malaysia and 
other Association of Southeast Asian Nations (ASEAN) countries.

\section{ACKNOWLEDGEMENT}

The authors would like to thank the DirectorGeneral of MPOB for permission to publish this article and CRAUN for the data and information supplied.

\section{REFERENCES}

Abd Aziz, S. (2002). Sago starch and its utilisation. Journal of Bioscience and Bioengineering, 94(6): 526-529.

Alamaria, A.M., Nawawi, M.G.M. \& Zamrud, Z. (2015). Sago/PVA blend membranes for the recovery of ethyl acetate from water. Arabian Journal of Chemistry, 12(8): 2183-2191.

Avraamides, M. \& Fatta, D. (2008). Resource consumption and emissions from olive oil production: A life cycle inventory case study in Cyprus. Journal of Cleaner Production, 16: 809821.

Bhat, R., Abdullah, N., Din, R.H. \& Tay, G.S. (2013). Producing novel sago starch based food packaging films by incorporating lignin isolated from oil palm black liquor waste. Journal of Food Engineering, 119: 707-713.

Bintoro, H.M.H., Purwanto, Y.J. \& Amarillis, S. (2010) Sagu di lahan gambut. IPB Press, Bogor. (in Indonesian).

Birkved, M. \& Hauschild, M.Z. (2006). PestLCI - A model for estimating field emissions of pesticides in agricultural LCA. Ecological Modelling, 198: 433451.

Chew, T.A., Md Isa, A.H. \& Mohyidin, M.G. (1998), The sago industry in Malaysia: Present status and future prospects. In Jin Z, Liang Q, Liang Y, Tan X and Guan L. (eds.). Proceedings of the 7th International Working Conference on StoredProduct Protection, 14-19 October 1998, Beijing, China. pp. 1720-1728.

Deep Resource (2012). Energy related conversion factors. Retrieved February 21st, 2020, from https://deepresource.wordpress.com/2012/04/23/en ergy-related-conversion-factors/

Flach, M. \& Schuilling, D.L. (1989). Revival of an ancient starch crop: A review of the agronomy of the sago palm. Agroforestry Systems, 7: 259-281.
Flach, M. (1997). Sago palm. Metroxylon sagu Rottb. Promoting the conservation and use of underutilized and neglected crops. 13. Institute of Plant Genetics and Crop Plant Research, Gatersleben/International Plant Genetic Resources Institute, Rome, Italy.

Halimah, M., Tan, Y.A., Nik Sasha, K.K., Zuriati, Z., Rawaida, A.I. \& Choo, Y.M. (2013). Determination of life cycle inventory and greenhouse gas emissions for a selected oil palm nursery in Malaysia: A case study. Journal of Oil Palm Research, 25(3): 343347.

Hansen, S. (2007). Feasibility study of performing an life cycle assessment on crude palm oil production in Malaysia. The International Journal of Life Cycle Assessment, 12: 50-58.

Howell, P.S., Abdullah, N.A.P., Busri, N., Bulan, P., Jiwan, M., Abdullah, Z.C. \& Ahmed, O.H. (2015). Food reserve composition in sago palm (Metroxylon sagu Rottb.) and influence of cluster age on survivability at the nursery stage. Proceeding Kuala Lumpur International Agriculture, Forestry and Plantation, 12-13 September 2015, Kuala Lumpur, Malaysia.

Ishizaki, A. (1997). Concluding remarks for the Sixth International Sago Symposium at Riau, Indonesia. Sago Communication 8 (pp. 22-25). Japan: Tsukuba Sago Fund.

Jamaludin, A.R., Kasim, S.R., Abdullah, M.Z. \& Ahmad, Z.A. (2014). Sago starch as binder and poreforming agent for the fabrication of porcelain foam. Ceramics International, 40: 4777-4784.

Jong, F.S. (2018). An overview of sago industry development, 1980s-2015. In Ehara H., Toyoda Y. Johnson D. (eds.) Sago Palm. Singapore: Springer. pp. 75-89.

Karim, A.A., Pei-Lang, A., Manan, D.M.A \& Zaidul, I.S.M. (2008). Starch from the sago (Metroxylon sagu) palm tree - properties, prospects and challenges as a new industrial source for food and other uses. Comprehensive Reviews in Food Science and Food Safety, 7: 215-228.

Khairuddin, N.S.K., Ismail, B.S., Muhamad, H. \& May, C.Y. (2013). Life cycle inventory for the production of germinated oil palm seeds at a selected seed production unit in Malaysia. AIP Conference Proceedings, 1571: 583-588.

McClatchey, W., Manner, H.I. \& Elevitch, C.R. (2006). Metroxylon amicarum, M. paulcoxii, M. sagu, $M$. salomonense, $M$. vitiense and $M$. warburgii (sago palm), ver. 2.1 In Elevitch CR (ed.). Species profiles 
for Pacific Island agroforestry. Holualoa, H.I. Permanent Agriculture Resources (PAR). Pp. 22.

Mohamad Naim, H., Yaakub, A.N. \& Awang Hamdan, D.A. (2016). Commercialization of sago through estate plantation scheme in Sarawak: The way forward. International Journal of Agronomy, 2016: $1-6$.

Pei-Lang, A.T., Mohamed, A.M.D. \& Karim, A.A (2006). Sago starch and composition of associated components in palms of different growth stages. Carbohydrate Polymers, 63: 283-286.

Shamsul, A. (2018). Sago starch 10 years' performance. Retrieved August 23, 2019, from https://data.sarawak.gov.my/home/data/dataset/847 0f507-a099-4c1e-9854-d1bebd140aa7

Singhal, R.S., John, F.K., Sajilata, M.G., Agnieszka, K., Charles, J.K. \& Putri, F.A. (2008). Industrial production, processing, and utilization of sago palm-derived products. Carbohydrate Polymers, 72:1-20.
Stanton, W.R. (1991). Long-term and ancillary environmental benefits from sago agroforestry systems. In Ng Thai-Tsiung, Tie Yiu-Liong \& Kueh Hong-Siong (eds.). Proceedings of the Fourth International Sago Symposium. 6-9 August 1991, Kuching, Malaysia. Pp. 24-35.

Wahi, R., Chuah, L.A., Ngaini, Z., Nourouzi, M.M. \& Choong, T.S.Y. (2014). Esterification of M. sagu bark as an adsorbent for removal of emulsified oil. Journal of Environmental Chemical Engineering, 2: 324-331.

Yahya, M., Mahyuddin, M., Alimon, A.R., Abdullah, N. \& Ivan, M. (2011). Sago pith meal based diets in sheep containing different sources of nitrogen: Feed preparation, growth performance, digestibility and carcass quality. Animal Feed Science and Technology, 170: 45-52. 